\title{
ANALISIS PENGARUH UKURAN PERUSAHAAN DAN UMUR PERUSAHAAN TERHADAP CORPORATE SOCIAI RESPONSIBILITY DISCLOSURE PADA PERUSAHAAN SEKTOR INDUSTRI DASAR DAN KIMIA DI BURSA EFEK INDONESIA PADA TAHUN 2013-2019
}

\author{
Sintia Safrianti \\ Universitas Prof Dr. Hazairin, SH \\ sintiasafrianti19@gmail.com
}

\begin{abstract}
The aim of the study is to know factors that influence Corporate Social Responsibility Disclosure in the Basic and Chemical Industry Sector. Variables investigated in this study were size of company and age of company. The method used in this study is tocollect data, and then it will be analyzed using quantitative analysis methods. The populations in this study were companies thatcarry out Social Responsibility Disclosure, 28 sample companies selected in this study used purposive sampling methodology. The data analysis method was multi linier regression with significance level of $5 \%$.

The result of the study showed that : (1) Company size has a significant effect on CSRD. This shows that large scale companies will do more disclosure of their social responsibility; (2) The age of the company is not significant for CSRD. This shows the length of the company does not affect the disclosure of social responsibility.
\end{abstract}

Keywords : corporate social responsibility disclosure, size of company, age of company

\section{PENDAHULUAN}

Saat sekarang ini di era globalisasi tingkat persaingan begitu ketat menyebabkan sebuah bisnis sangat perlu memperhatikan keberlangsungan hidup perusahaannya agar tetap survive. Untuk dapat membuat perusahaan bertahan lama dan mampu bersaing, setiap perusahaan dituntut untuk lebih terbuka dalam penyampaian informasi sehingga informasi dapat di terima dan diketahui dengan baik oleh masyarakat luas terutama untuk perusahaan yang telah go public di pasar modal. Informasi tanggung jawab sosial perusahaan dapat digambarkan sebagai ketersediaannya informasi keuangan maupun non-keuangan yang berkaitan dengan interaksi organisasi dengan lingkungan fisik serta lingkungan sosialnya, yang dapat dimuat dalam laporan tahunan perusahaan.

Menurut The World Business Council on Sustainable Development (WBCSD) dalam (Sari, 2012) Corporate Social Responsibilit yadalah komitmen perusahaan dalam menjalankan kegiatan operasinya untuk dapat senantiasa memberikan kontribusi positif terhadap masyarakat sosial dan lingkungan sekitarnya. Corporate Social Responsibility (CSR) merupakan suatu konsep akuntansi yang dapat membawa perusahaan agar melaksanakan tanggung CSR yang timbul sebagai akibat dari keberadaan perusahaan-perusahaan yang aktivitasnya selain dapat memberi manfaat akan tetapi dapat menimbulkan banyak dampak negatif pula terhadap masyarakat (Dewi, 2015). Masyarakat sekitar yang berada dekat dengan perusahaan lah yang biasanya akan merasakan dampak negatif tersebut. Sejak tahun 1960, isu mengenai pengungkapan CSR sudah mulai didiskusikan di Amerika Serikat. Pada akhirnya tahun 2000, 
Global Reporting Initiative (GRI) yang merupakan program dari Perserikatan Bangsa-Bangsa membuat pedoman mengenai sustainability reporting yang digunakan perusahaan dalam pengungkapankegiatan CSR-nya. Pada penelitian ini akan menggunakan indikator penilaian berdasarkan Global Reporting Initiative (GRI) tersebut.

Informasi tentang tanggung jawab perusahaan yang sekarang menjadi kewajiban bagi setiap perusahaan ternyata sangat mempengaruhi keberlangsungan perusahaan karena informasi tersebut digunakan sebagai dasar bagi mereka yang berhubungan dengan perusahaan secara langsung maupun tidak langsung diantaranya yaitu para investor dan calon investor sebagai dasar pengambilan keputusan investasi, karyawan perusahaan sebagai bahan dasar untuk memperkirakan keberlangsungan nasib mereka bekerja di dalam perusahaan, para pihak eksternal baik yang berhubungan langsung maupun tidak langsung yang menggunakan laporan tanggung jawab sosial perusahaan sebagai bahan acuan dasar untuk mengawasi dan mengontrol jalannya kegiatan perusahaan agar dapat menciptakan keadaan yang serasi antara perusahaan dan lingkungan sosial sekitar (Khadifa dan hariri, 2014).

Sebelum tahun 2007 pengungkapan tanggung jawab sosial perusahaan masih sekedar bersifat sukarela ata seadanya, dari hal tersebut pemerintah Indonesia membuat Undang-Undang Nomor 40 Tahun 2007 tentang Perseroan Terbatas yang menjadi titik awal pelaksanaan CSR di Indonesia. Keempat ayat dalam pasal 74 Undang-undang Nomor 40 Tahun 2007 tersebut menetapkan kewajiban semua perusahaan dibidang sumber daya alam untuk melaksanakan tanggung jawab sosial dan lingkungan (Ulum, 2011). Sejak adanya peraturanper Undang-undang tersebut satu persatu perusahaan yang go public dan tercatat di Bursa Efek Indonesia mulai harus mengungkapkan aktivitas tanggung jawab sosialnya dalam laporan keuangan tahunannya, terlebih lagi perusahaan yang bidang usahanya berkaitan dengan lingkungan.

Dari latar belakang diatas, maka penulis tertarik untuk meneliti lebih lanjut mengenai faktor-faktor yang mempengaruhi Corporate Social Responsibility Disclosure dengan judul "Analisis Pengaruh Ukuran Perusahaan dan Umur Perusahaan Terhadap Corporate Social Responsibility Disclosure pada Perusahaan Sektor Industri Dasar dan Kimia di Bursa Efek Indonesia pada Tahun 2013-2019““

\section{LANDASAN TEORI}

\section{Teori Stakeholder}

Menurut Ghazali dan Chariri (2007) teori stakeholder merupakan teori yang menjelaskan bahwa perusahaan bukanlah entitas yang hanya beroperasi untuk kepentingan perusahan itu sendiri, tapi harus mampu memberikan manfaat kepada seluruh stakeholder-nya (pemegang saham, kreditor, konsumen, supplier, pemerintah, masyarakat, analis, dan pihak lain). Perusahaan yang menjalankan CSR akan biasanya akan memperhatikan dampak terhadap kondisi sosial dan lingkungannya, serta berupaya agar dampak yang dihasilkan merupakan dampak yang positif untuk lingkungan dan masyarakat bukan dampak negatif.

\section{Teori Keagenan}

Teori Agensi merupakan teori yang menjelaskan mengenai bagaimana hubungan antara principal (pemilik perusahaan) dengan agent (manajer). Yang dimaksud dengan agen adalah pihak yangmengelola perusahaan tersebut, seperti manajer perusahaan atau dewan direksi yang bertindak sebagai pembuat keputusan dalam menjalankan kegiatan perusahaan, sedangkan arti dari principal adalah pihak yang mengevaluasi informasi, yaitu seperti pemegang saham 
perusahaan (Ghazali dan Chariri, 2007). Dari pengertian tersebut maka pengungkapan CSR dapat dikaitkan dengan agency theory.

\section{Teori Legitimasi}

Teori legitimasi menyatakan bahwa perusahaann yang secara terus menerus mencoba untuk meyakinkan bahwa kegiatan atau aktivitas yang dilakukan perusahaan sesuai dengan batasan dan norma-norma pada masyarakat dimana perusahaan tersebut beroperasi atau berada. Kegiatan perusahaan dapat menimbulkan dampak sosial dan lingkungan, sehingga pada praktik pengungkapan sosial dan lingkungan merupakan alat manajerial yang digunakan perusahaan untuk menghindari konflik sosial dan lingkungan (Ghozali dan Chariri, 2007).

\section{Corporate Social Responsibility Disclosure}

Kewajiban sosial harus dimiliki sebuah perusahaan atas apa yang terjadi pada lingkungan disekitar masyarakat diamana perusahaan tersebut beroperasi atau berada. Selain menggunakan dana yang berasal dari para pemegang saham, perusahaan juga menggunakan dana yang bersumber dari masyarakat (konsumen) sehingga merupakan hal yang wajar jika masyarakat mempunyai harapan tertentu terhadap perusahaan tersebut. corporate social responsibility merupakan mekanisme bagi suatu organisasi yang secara sukarela mengintegrasikan perhatian terhadap lingkungan dan sosial ke dalam operasinya dan interaksinya dengan para stakeholders, yang bukan hanya tanggung jawab organisasi di bidang hukum (Saputra, 2016).

Pengungkapan corporate social responsibility perusahaan juga merupakan suatu proses mengkomunikasikan dampak sosial apa saja yang merupakan dampak dari kegiatan ekonomi organisasi terhadap masyarakat secara keseluruhan atau terhadap suatu kelompok khusus yang memiliki kepentingan (Ali dan Rizwan, 2013). Selain itu pengungkapan corporate social responsibility juga merupakan sarana yang digunakan oleh para menajemen perusahaan dalam berinteraksi dengan masyarakat luas untuk dapat mempengaruhi persepsi, selain itu melalui pengungkapan corporate social responsibility ini para stake holder juga dapat mengetahui dan memberikan respon mengenai aktivitas yang telah dilakukan oleh perusahaan terkait. Pada Undang-undang Nomor. 40 tahun 2007 kewajiban pengungkapan tanggung jawab sosial telah diatur dalam pasal 66 ayat 2c yang menyatakan bahwa semua perseroan wajib untuk melaporkan pelaksanaan tanggung jawab sosial dan lingkungan dalam laporan tahunan. Pedoman pengungkapan tanggung jawab sosial perusahaan yang banyak digunakan oleh perusahaan global termasuk di Indonesia adalah dengan Global Reporting Initiative (GRI) (Waluyo, 2017).

\section{Ukuran Perusahaan}

Ukuran perusahaan adalah suatu skala dimana dapat diklasifikasikan besar ataupun kecil suatu perusahaan. Ukuran perusahaan menunjukkan besar kecilnya suatu perusahaan dan struktur kepemilikan yang lebih luas (Utami dan Prastiti, 2011). Perusahaan yang skalanya besar biasanya cenderung lebih banyak dalam mengungkapkan tanggung jawab sosialnya daripada perusahaan yang mempunyai skala lebih kecil (Sari, 2012). Agar perusahaan dalam jangka waktu panjang bisa terhindar dari biaya yang sangat besar akibat dari tuntutan masyarakat maka perusahaan dapat mengungkapkan kepeduliannya pada lingkungan melalui pelaporan keuangan tahunan.Ukuran perusahaan dapat dikaitkan dengan teori agensi, dimana dijelaskan pada perusahaan besar yang memiliki biaya keagenan yang lebih besar dari perusahaan keciluntuk dapat mengurangi biaya keagenan yang besar tersebut perusahaan akan mengungkapkan informasinya yang lebih luas. Perusahaan kecil yang mungkin tidak menunjukkan 
pengungkapantanggung jawab sosial secara jelas dikarenakan perusahaan tersebut baru akan tumbuh.Pengukuran pada ukuran perusahaan dilaporan keuangan diproksikan dengan menggunakan logaritma natural dari total aktiva perusahaan tersebut.

\section{Umur Perusahaan}

Umur perusahaan menunjukkan kemampuan perusahaan dalam seberapa lama dapat bertahan hidup. Perusahaan yang semakin lama/panjang umur nya maka informasi yang akan didapat oleh masyarakat mengenai perusahaan tersebut akan semakin banyak, sehingga semakin lama sebuah perusahaan dapat bertahan, maka perusahaan tersebut semakin banyak mengungkapkan informasi sosialnya kepada masyarakat sebagai bentuk tanggung jawabnya agar dapat tetap diterima di masyarakat. Pada variabel umur perusahaan diperkirakan akan memiliki hubungan positif dengan penguungkapan tanggung jawab sosail. Umur perusahaan dapat dikaitkan dengan teori legitimasi, dimana menurut teori ini organisasi dapat dilihat sebagai sesuatu yang diberikan masyarakat kepada perusahaan dan sesuatu yang diinginkan atau dicari perusahaan dari masyarakat (Utami dan Prastiti, 2011). Variabel umur perusahaan dapat diukur dengan berdasarkan waktu sejak perusahaan mulai didirikan sesuai akta hingga perusahaan tersebut dijadikan sampel dalam penelitian ini.

\section{Kerangka Analisis}

Variabel Independen

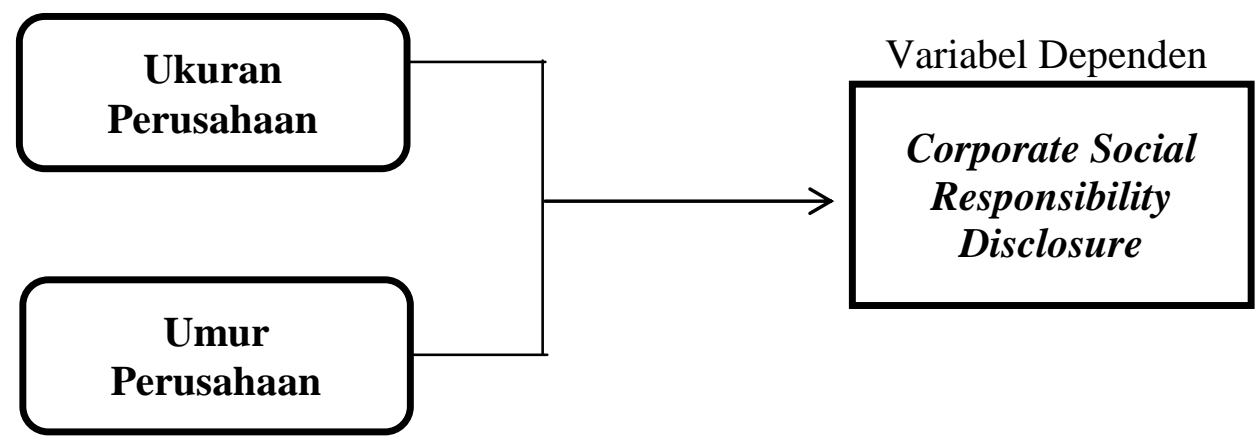

Hipotesis yang akan ditarik dari penelitian ini adalah :

$\mathrm{Ha}_{1}$ : Ada pengaruh ukuran perusahaan dan umur perusahaan secara simultan terhadap CSRD $\mathrm{Ha}_{2}$ : Ada pengaruh ukuran perusahaan secara parsial terhadap CSRD

$\mathrm{Ha}_{3}$ : Ada pengaruh umur perusahaansecara parsial terhadap CSRD

\section{METODOLOGI}

Penelitian ini menggunakan pendekatan kuantitatif yaitu penelitian terhadap masalahmasalah, yang berupa fakta-fakta pada saat ini dari suatu populasi, dan dengan menggunakan data sekunder (Ramadhani dan Mashariono, 2017).

Data-data dikumpulkan dengan cara menggunakan metode dokumentasi, dimana semua data sekunder yang ada didalam laporan keuangan perusahaan dan annual report perusahaan dikumpulkan, serta segala informasi yang terdapat pada jurnal-jurnal, buku dan media infomasi lainnya yang digunakan untuk penelitian ini. Data yang akan diolah pada penelitian ini meliputi data dari annual report dan laporan keuangan pada tahun 2013-2019. Data yang digunakan tersebut didapat dari web Bursa Efek Indonesia atau www.idx.co.id . 
Pada penelitian ini mengambil populasi perusahaan yang melakukan pengungkapan tanggung jawab sosialnya, sedangkan sampel yang digunakan yaitu perusahaan pada sektor industri dasar dan kimia yang terdaftar di BEI tahun 2013-2019, dimana terdiri dari 69 perusahaan sektor industri dasar dan kimia. Teknik pengambilan sampel pada penelitian ini adalah dengan menggunakan teknik purposive sampling. Berdasarkan karakteristik yang sesuai, terdapat perusahaan yang tidak menerbitkanlaporan CSR nya atau annual report perusahaan pada periode 2013-2019 diamana sebanyak 25 perusahaan dan perusahaan yang tidak menggunakan mata uang rupiah $(\mathrm{Rp})$ tercatat sebanyak 16 perusahaan. Sehingga penulis menemukan 28 sampel perusahaan pada sektor industri dasar dan kimia dari 69 perusahaan sektor industri dasar dan kimia yang terdaftar di Bursa Efek Indonesia (BEI) yang memenuhi syarat sebagai sampel untuk di analisis lebih lanjut pada penelitian ini.

Tabel Sampel

\begin{tabular}{|l|l|c|}
\hline No & \multicolumn{1}{|c|}{ Kriteria Penarikan Sampel } & Jumlah \\
\hline 1. & $\begin{array}{l}\text { Jumlah perusahaan pada sektor industri dasar dan kimia yang } \\
\text { terdaftar di BEI pada tahun 2013-2019 }\end{array}$ & 69 \\
\hline 2 & $\begin{array}{l}\text { Perusahaan yang tidak menerbitkan laporan CSR atau annual } \\
\text { report } \text { masing-masing perusahaan untuk periode 2013-2019 }\end{array}$ & 25 \\
\hline 3 & Perusahaan yang tidak menggunakan mata uang rupiah & 16 \\
\hline & Jumlah perusahaan sampel & 28 \\
\hline
\end{tabular}

Sumber: data sekunder yang diolah

Metode yang digunakan dalam penelitian ini adalah dengan mengumpulkan data-data, dan selanjutnya akan dianalisis menggunkan metode analisis kuantitatif. Menurut Sugiyono (2012), metode penelitian kuantitatif dapat diartikan sebagai metode penelitian yang berlandaskan pada filsafat positivisme, digunakanuntuk meneliti pada populasi atau sampel tertentu. Model analisis kuantitatif meruapakan metode yang menganalisis data yang berbentuk angka-angka dari data statistik dan selanjutnya data dapat dikelompokkan berdasarkan variabel dan mentabulasikannya. Daftar perusahaan yang termasuk kategori perusahaan sektor industri dasar dan kimia diperoleh dari situs http://www.sahamok.com, dan data laporan tahunan dan laporan keuangan perusahaan yang digunakan diperoleh dari situs http://www.idx.go.id. Penelitian ini menggunakan metode analisis kuantitatif yaitu dengan menggunakan metode analisis regresi berganda, yang bertujuan mengukur pengaruh variabel bebas terhadap variabel terikat. Perhitungan analisis regresi ini menggunakan bantuan program SPSS statisticts versi 25.0 for windows.

\section{Statistik Deskriptif}

Statistik deskriptif merupakan pemberian gambaran atau deskripsi suatu data yang dapat dilihat dari nilai rata-rata (mean), standart deviasi, varian, maksimum, minimum, sum, range, kurtosis, dan skewness (Ghozali, 2011). Tujuan dari analisis statistik deskriptif ini adalah untuk memberikan gambaran atau deskripsi dari variable-variabel yang diteliti agar lebih mudah dipahami. 


\section{Pengujian Asumsi Klasik}

Uji Normalitas

Menurut Ghozali, (2011)Uji normalitas bertujuan untuk menguji apakah pada model regresi berganda yaitu antara variabel terikat dan variabel bebas mempunyai distribusi normal atau tidak.

Uji Multikolinearitas

Uji multikoleniaritas bertujuan untuk menguji apakah model regresi ada ditemukan korelasi antar variabel bebas (independen) atau tidak. Model regresi yang baik mensyaratkan tidak terjadinya multikolinearitas. Menurut Ghozali (2011) yang umum diguanakan untuk menunjukan tidak adanya multikolinearitas adalah dengan mengguanakan nilai tolerance $\geq$ 0,10 atau sama dengan nilai $\mathrm{VIF} \leq 10$

Uji Heteroskedastisitas

Uji heterokedastisitas bertujuan menguji apakah pada model regresi terjadi ketidaksamaan varians dari residual satu pengamatan ke pengamatan yang lain. Dasar analisisnya adalah jika tidak ada pola yang jelas, serta titik-titik menyebar diatas dan dibawah angka 0 pada sumbu Y, maka tidak terjadi heteroskedastisitas (Ghozali, 2011).

Uji Autokorelasi

Uji autokorelasi bertujuan menguji apakah dalam model regresi linier ada korelasi antara kesalahan pengganggu pada periode $t$ dengan kesalahan pengganggu t-1. Model regresi yang baik adalah regresi yang bebas atau tidak ada autokorelasi. Pengujian autokorelasi ini dengan menggunakan uji Durbin-Watson.

\section{Analisis Regresi Berganda}

Metode analisis yang digunakan dalam penelitian ini adalah dengan analisis regresi berganda (Multiple Regression). Analisis Regresi Berganda digunakan untuk melihat hubungan atau ketergantungan antara variabel dependen (terikat) dengan variabel-variabel independen (variabel bebas) yang telah ditetapkan dalam penelitian.

\section{Uji Hipotesis}

Untuk menguji hipotesis yang diajukan tentang hubungan variabel independen dengan variabel dependen dapat digunakan alat analisis statistik yaitu uji t dan uji f.

5. Koefisien Determinasi $\left(R^{2}\right)$

Nilai R2 memiliki kelemahan bias terhadap jumlah variabel independen yang dimasukkan kedalam model, sehingga dalam penelitian ini akan menggunakan nilai adjusted R2 pada saat mengevaluasi model regresi terbaik (Ghozali, 2011). 


\section{HASIL DAN PEMBAHASAN}

1. Pengujian Asumsi Klasik

1.1 Uji Normalitas

Output Uji Normalitas

One-Sample Kolmogorov-Smirnov Test

\begin{tabular}{|l|r|r|r|}
\hline & \multicolumn{1}{|c|}{ Y } & \multicolumn{1}{c|}{ SIZE } & \multicolumn{1}{c|}{ AGE } \\
\hline $\mathrm{N}$ & 196 & 196 & 196 \\
Kolmogorov-Smirnov Z & 2.858 & 1.194 & .881 \\
Asymp. Sig. (2-tailed) & .000 & .116 & .419 \\
\hline
\end{tabular}

Pada tabel diperolah hasil besarnya signifikan pada variabel ukuranperusahaan adalah 0,116 maka data terdistribusi normal karena nilai signifikasi lebih dari 0,05 dan pada variabel umur perusahaanbesarnya signifikan adalah 0,419yang artiya lebih besar dari 0,05 maka data terdistribusi normal juga.

\subsection{Uji Multikolinearitas}

\begin{tabular}{|c|c|c|c|}
\hline \multirow{2}{*}{\multicolumn{2}{|c|}{ Model }} & \multicolumn{2}{|c|}{ Collinearity Statistics } \\
\hline & & Tolerance & VIF \\
\hline \multirow[t]{3}{*}{1} & (Constant) & & \\
\hline & SIZE & .990 & 1.010 \\
\hline & AGE & .990 & 1.010 \\
\hline
\end{tabular}

Dari tabel diketahui nilai toleransi dari dua variabel independen adalah lebih dari 0,10 dan nilai VIF enam variabel kurang dari 10, maka disimpulkan bahwa tidak adanya masalah multikolinearitas.

1.3 Uji Heteroskedastisitas

Grafik Scatterplot Uji Heteroskedastisitas

Scatterplot

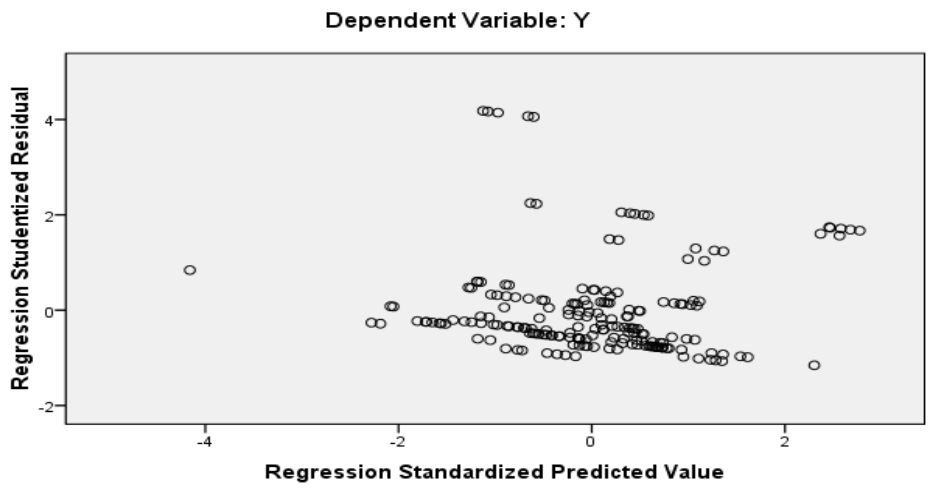


Dari grafik scatterplot tersebut dapat dilihat bahwa titik-titik menyebar dengan pola yang tidak jelas diatas dan dibawah angka 0 pada sumbu $\mathrm{Y}$, maka tidak terjadi masalah heteroskedastisitas pada model regresi.

\subsection{Uji Autokorelasi}

\begin{tabular}{|l|lr|}
\multicolumn{2}{c}{ Ouput Uji Autokorelasi } \\
\hline Model & \multicolumn{2}{|c|}{ Durbin-Watson } \\
\hline 1 & & 2.120 \\
\hline
\end{tabular}

Dengan jumlah $\mathrm{n}=196, \mathrm{k}=2, \alpha=5 \%$, dari Tabel 3.5 dapat diketahui tabel Durbin Watson didapatkan $\mathrm{dL}=1,7456$ dan $\mathrm{dU}=.1,7868$ Maka 4- $\mathrm{dL}=2,2544$ dan 4-dU= 2,2132 Dengan nilai $\mathrm{d}$ pada tabel 2,120, sehingga dapat diketahui $1,7868<2,120<2,2132$ yang artinya tidak adanya auto korelasi.

\section{Analisis Regresi Berganda}

Metode analisis yang digunakan dalam penelitian ini adalah dengan analisis regresi berganda (Multiple Regression). Analisis Regresi Berganda digunakan untuk melihat hubungan atau ketergantungan antara variabel dependen (terikat) dengan variabel-variabel independen (variabel bebas) yang telah ditetapkan dalam penelitian .

$$
\mathrm{Y}=\mathrm{a}+\mathrm{b}_{1} \mathrm{X}_{1}+\mathrm{b}_{2} \mathrm{X}_{2}
$$

$$
\begin{aligned}
& \text { Keterangan : } \\
& \mathrm{Y}=\text { CSRD } \\
& \mathrm{a}=\text { Konstanta } \\
& \mathrm{X}_{1}=\text { Ukuran perusahaan } \\
& \mathrm{X}_{2}=\text { Umur perusahaan } \\
& \mathrm{b}_{1}=\text { Koefisien regresi ukuran perusahaan } \\
& \mathrm{b}_{2}=\text { Koefisien regresi umur perusahaan } \\
& \mathrm{e}=\text { error term }
\end{aligned}
$$

\begin{tabular}{|c|c|c|c|c|c|}
\hline \multirow{2}{*}{\multicolumn{2}{|c|}{ Model }} & \multicolumn{2}{|c|}{ Unstandardized Coefficients } & \multirow[b]{2}{*}{$\mathrm{t}$} & \multirow[b]{2}{*}{ Sig. } \\
\hline & & $\mathrm{B}$ & Std. Error & & \\
\hline \multirow[t]{3}{*}{1} & (Constant) & -.286 & .188 & -1.518 & .131 \\
\hline & SIZE & .015 & .007 & 2.361 & .019 \\
\hline & AGE & .003 & .002 & 1.758 & .080 \\
\hline
\end{tabular}

Ouput Regresi Berganda

Berdasarkan tabel diatas didapatkan persamaan regresi sebagai berikut :

$\mathrm{CSRD}=-0,286+0,015 \mathrm{X} 1+0,003 \mathrm{X} 2$

Berdasarkan nilai konstanta yang didapat sebesar -0,286 menunujukan arah negatif, ini menunjukan bahwa jika koefesien regresi variabel independen (ukuran perusahaan dan umur perusahaan) dianggap nol atau tidak ada perubahan, maka nilai CSRD tetap sebesar -0,286. Koefesien untuk ukuran perusahaan sebesar 0,015 hal ini menunjukan jika setiap ukuran 
perusahaan mengalami peningkatan sebesar 1 poin maka CSRD akan mengalami peningkatan sebesar 0,015 dengan asumsi koefesien regresi variabel lain adalah tetap. Selanjutnya koefesien regresi umur perusahaan sebesar 0,003 ini menunjukan jika umur perusahaan mengalami peningkatan sebesar 1 poin maka CSRD mengalami peningkatan sebesar 0,003 dengan asumsi koefesien regresi variabel lain adalah tetap.

\section{Deskriptif Statistik}

Statistik deskriptif ini meggambarkan bagaimana keadaan semua perusahaan yang menjadi sampel dari nilai minimum, maksimum, rata-rata dan standar deviasi. Deskriptif statistik dalam penelitian ini adalah sebagai berikut :

\begin{tabular}{|l|r|r|r|r|r|}
\multicolumn{7}{|c|}{ Ouput Deskriptif Statistik } \\
\hline & $\mathrm{N}$ & Minimum & Maximum & Mean & $\begin{array}{c}\text { Std. } \\
\text { Deviation }\end{array}$ \\
\hline Y & 196 & .05 & 1.08 & .2599 & .21390 \\
SIZE & 196 & 15.983 & 34.266 & $2.78516 \mathrm{E} 1$ & 2.303835 \\
AGE & 196 & 18 & 66 & 39.32 & 9.079 \\
Valid N (listwise) & 196 & & & & \\
\hline
\end{tabular}

Dari Tabel diatas dapat diketahui bahwa dari 28 sampel perusahaan selama 7 tahun sehingga jumlah $\mathrm{N}$ adalah sebanyak 196 observasi. tingkat rata-rata CSRD di Bursa Efek Indonesia sebesar 0,2599\%. Nilai CSRD sebesar 25,99\% menunjukkan nilai pengungkapan yang cukup rendah karena secara keseluruhan perusahaan sampel masih sedikit mengungkapkan item-item tanggung jawab sosial dalam laporan tahunan perusahaan. Dimana tingkat CSRD yang paling rendah sebesar $0,05 \%$, hal ini menunjukkan bahwa perusahaan tersebut tidak melakukan pengungkapan tanggung jawab sosial dalam laporan tahunan berdasarkan indeks GlobalReporting Initiative (GRI). Sedangkan tingkat corporate social responsibility disclosure tertinggi yaitu sebesar 1,08\%, hal ini menunjukkan bahwa perusahaantersebut sudah melakukan pengungkapan tanggung jawab sosial dalam laporan tahunan berdasarkan indeks Global Reporting Initiative (GRI). Standar deviasi sebesar 0,21390\% yang menunjukan terdapat variasi antara CSRD pada perusahaan yaitu sebesar 2,1390\%, hal ini lebih besar dari nilai rata-rata menunjukkan bahwa data variabel CSRD yang digunakan dalam penelitian ini sudah bervariasi.

\section{Uji Hipotesis}

\section{Uji F / Uji simultan}

Uji $\mathrm{F}$ pada dasarnya menunjukkan apakah ada pengaruh secara bersama-sama antara variabel

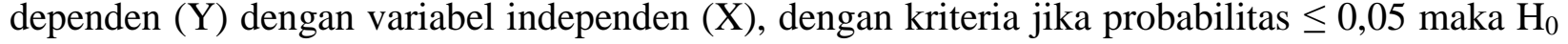
ditolak dan $\mathrm{Ha}_{1}$ diterima.

Ouput Uji Simultan
\begin{tabular}{|ll|r|r|}
\hline Model & & F & \multicolumn{1}{c|}{ Sig. } \\
\hline 1 & Regression & 4.783 & $.009^{\mathrm{a}}$ \\
& & & \\
& & & \\
\hline
\end{tabular}


Berdasarkan hasil perhitungan tersebut diketahui nilai probabilitas 0,009 dan dengan nilai signifikansi 0,05. Dengan nilai probabilitas lebih kecil dari nilai signifikansi yaitu $0,009<0,05$, yang artinya ada pengaruh ukuran perusahaan dan umur perusahaan secara simultan terhadap corporate social responsibility disclosure.

\section{Uji t / Uji parsial}

Pengujian secara parsial dilakukan untuk membuktikan apakah terdapat pengaruh ukuran perusahaan dan umur perusahaan secara parsial terhadap corporate social responsibility disclosure.

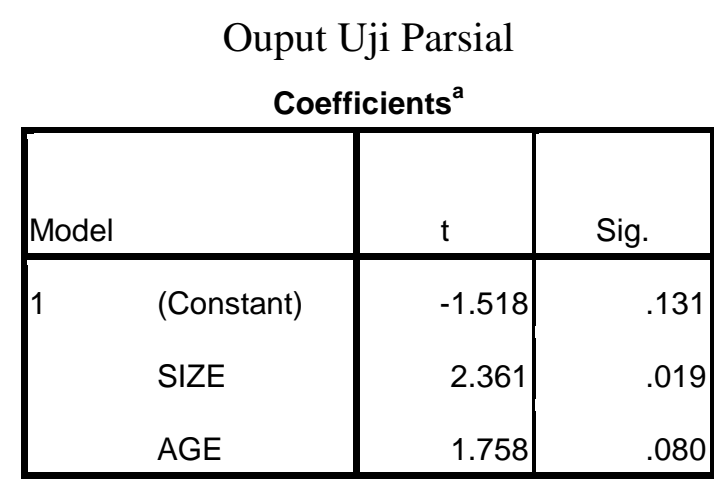

Pengujian parsial pertama pengaruh ukuran perusahaan terhadap CSRD mendapatka hasil nilai probabilitas sebesar $0,019<0,05$, ini berarti ada pengaruh ukuran perusahaan corporate social responsibilitydisclosure. Hal ini menunjukan bahwa CSRD bergantung pada besar atau kecilnya suatu perusahaan. Adapaun hasil yang didapatkan ini menunjukan bahwa perusahaan dengan skala besar akan melakukan lebih banyak pengungkapan tanggung jawab sosialnya melalui aktivitas yang memberikan dampak lebih besar terhadap masyarakat. Penelitian ini juga berhasil mendukung teori legitimasi yaitu perusahaan besar akan mengungkapkan tanggung jawab sosial lebih tinggi agar perusahaan tetap mendapatkan respon yang positif dari pihak lain, sehingga aktivitas usaha dapat berjalan dengan lancar.

Pengujian parsial kedua yaitu pengaruh umur perusahaan terhadap CSRD. Pengambilan keputusan berdasarkan jika nilai probabilitas > 0,05 makai umur perusahaan diterima dan sebaliknya. Pada tabel diatas dapat dilihat bahwa nilai probilitas adalah 0,80 , yang artinya 0,80>0,05, maka tidak ada pengaruh umur perusahaan secara parsial terhadap CSRD.Umur perusahaan yang telah lama berdiri seharusnya mampu menyerap berbagai informasi untuk membantu perusahaan tumbuh secara keberlanjutan dan perusahaan dapat melakukan kegiatan CSR yang lebih baik lagi dari tahun sebelumnya, akan tetapi pada penelitian ini hal tersebut tidak mempengaruhi dan hasil ini juga tidak sejalan dengan teori legitimasi karena menurut teori ini seharusnya semakin lama perusahaan maka semakin banyak informasi yang telah diperoleh masyarakat tentang perusahaan tersebut.

\section{Koefisien Determinasi}

Koefesien Determinasi $\left(\mathrm{R}^{2}\right)$ mengukur seberapa jauh kemampuan model dalam menerangkan variasi variabel dependen. 


\begin{tabular}{|l|c|r|r|}
\multicolumn{4}{|c}{ Ouput Koefesien Determinasi } \\
\hline Model & \multicolumn{1}{|c|}{ R } & R Square & Adjusted R Square \\
\hline 1 & $.217^{\mathrm{a}}$ & .047 & .037 \\
\hline
\end{tabular}

Dari hasil diatas didapatkan angka $\mathrm{R}$ sebesar 0,217 yang berarti hubungan antara variabel dependen dan variabel independen mempunyai tingkat hubungan sebesar $21,7 \%$. Selain itu angka Adjusted $R$ Square adalah pada tabel diatas menunjukan pada angka 0,037.

\section{SIMPULAN}

Penelitian ini bertujuan untuk meneliti faktor-faktor yang mempengaruhi CSRD pada perusahaan-perusahaan yang termasuk pada sektor dasar dan kimia di Bursa Efek Indonesia pada tahun 2013-2019. Penelitian dilakukan pada 28 perusahaan dan total observasi N=196. Maka berdasarkan hasil penelitian dan pembahasan diperoleh kesimpulan bahwa ukuran perusahaan berpengaruh signifikan terhadap CSRD. Hal ini menunjukan bahwa perusahaan dengan skala besar akan melakukan lebih banyak pengungkapan tanggung jawab sosialnya melalui aktivitas yang memberikan dampak lebih besar terhadap masyarakat. Sedangkan pada variabel umur perusahaan tidak berpengaruh signifikan terhadap CSRD. Hal ini menunjukkan karena lamanya perusahaan tersebut berdiri tidak mempengaruhi pengungkapan tanggung jawab sosialnya.

Berdasarkan hasil penelitian dan kesimpulan yang diperoleh, maka saran yang dapat diberikan adalah bagi perusahaan dengan total asset yang dibawah rata-rata agar dapat meningkatkan total assetnya, karena semakin tinggi total asset maka akan semakin tinggi juga pencapaian dalam suatu perusahaan termasuk dalam pelaksanaan CSRD.Sedangkan untuk investor juga harus memperhatikan faktor-faktor apa saja yang dapat mempengaruhi CSRD, karena hal tersebut juga bisa menjelaskan kondisi dari perusahaan itu sendiri.

\section{DAFTAR PUSTAKA}

Aini,Agustya Kurratul, 2015, Pengaruh Karakteristik Perusahaan Terhadap Pengungkapan Tanggung Jawab Sosial Perusahaan (CSR) pada Perusahaan yang Terdaftar di Indeks LQ 45 Bursa Efek Indonesia (BEI), Kinerja, Vol. 12, No. 1, 1-11.

Ali, Waris and Rizwan, Muhammad, 2013, Factors Influencing Corporate Social And Environmental disclosure (Csed) Practices In The Developing Countries: An Institutional Theoretical Perspective, InternationalJournal Of Asian Social Science, Vol. 3, No. 3, 590609.

Dewi, Syahrina Noormala, 2015, Pengaruh KarakteristikPerusahaan Terhadap Pengungkapan Corporate SocialResponsibility (CSR),Bisnis, Vol. 3, No. 2, Desember , 364-393.

Ghozali, Imam, 2011, Aplikasi Analisis Multivariate Dengan Program IBM SPSS19, Badan Penerbit UNDIP, Semarang.

Khadifa Ramanitya, Chariri Anis, 2014, Pengaruh Kinerja Lingkungan, Size, Profitabilitas, Ukuran Dewan Komisaris, Profile,Leverage, dan Konsentrasi Kepemilikan Perusahaan Terhadap CSR Disclosure di Perusahaan Manufaktur yang Terdaftar di Bursa Efek Indonesia (BEI) Tahun 2010-2012, Diponegoro Journal Of Accounting, Vol 3, No 4, 1-10.

Ramadhani, Fida Nuzula dan Mashariono, 2017, Analisis Pengaruh Kinerja Keuangan Terhadap Tanggung Jawab Sosial Perusahaan, Jurnal Ilmudan Riset Manajemen, Vol. 6, No. 7, 115. 
Saputra, Syailendra Eka, 2016, Pengaruh Leverage, Profitabilitas dan Size Terhadap Pengungkapan corporate social responsibility Pada Perusahaan Di Bursa Efek Indonesia, Journal Of Economic AndEconomic Education, Vol. 5, No. 1, 75-89.

Sari, Rizkia Anggita, 2012, Pengaruh Karakteristik Perusahaan Terhadap corporate social responsibility disclosure pada Perusahaan Manufaktur yang Terdaftar di Bursa Efek Indonesia, Jurnal Nominal, Vol. I, No. I, 124-140.

Sugiyono, 2010, Statistik untuk Penelitian, Jakarta, Alfabet

Ulum, Ihyaul, Wahjuni, Endang Dwi dan Sasongko, Dian Edi, 2011, Pengaruh Karakteristik Perusahaan Terhadap corporate social responsibility Diclosure pada Official Website Perusahaan Publik di Indonesia, Vol. 14, No . 2, 25-40.

Utami, Sari dan Prastiti, Sawitri Dewi, 2011, Pengaruh Karakteristik Perusahaan Terhadap Social disclosure, Jurnal Ekonomi Bisnis, Vol. 1, No . 1, 63-69.

Waluyo, 2017, Firm Size, Firm Age, and Firm Growth on corporate social responsibility in Indonesia: The Case Of Real Estate Companies, European Research Studies Journal, Vol. 20, No. 4, $360-369$. 